\title{
Challenges of International Migration in a Globalized World: Implications for Europe
}

\author{
${ }^{1}$ Gratiela Georgiana Noja, ${ }^{2}$ Liana Son \\ 1,2 PhD Lecturer, Faculty of Economics and Business Administration, West \\ University of Timisoara, Romania
}

\begin{abstract}
The research conducted aims to identify and assess the interdependencies between international migration and labour market outcomes, focusing both on emigration and immigration effects on sending, and destination countries, as well as on economic (labour force) and non-economic (humanitarian, refugees) migration. International migration as one of the most important frontiers of globalization represents a major challenge globally, with significant economic consequences, especially for Europe, where large migrant flows have emerged in the context of European integration. Moreover, recently there is an increased waves of refugees and asylum seekers targeting Germany, Austria, Sweden or Turkey as main destination countries coming through Eastern and Central Mediterranean or Western Balkans routes. The analysis is based on developing various double-log fixed and random effects models, as well as dynamic models, using a panel structure that covers five main EU destination countries (Germany, Austria, Sweden, Italy and Spain) and three New EU Member States since 2007 and 2013 (Romania, Bulgaria, Croatia). We used a complex set of indicators (national accounts - GDP total, per capita, per person, employed; labour market employment, unemployment, wages, secondary and tertiary education; migration specific data immigration flows and stocks, asylum seekers and refugees, emigrant stocks), compiled during 20002014. Moreover, we used a SEM model (Structural Equations Modelling) to better capture the labour market impacts of international migration for the selected EU countries. The models are processed through OLS, GLS, and MLE methods, as well as by using panel corrected standard errors, and are completed within and out-of-sample predictions. The results show that immigration flows have important economic consequences leading to significant changes in labour market performances (slight decrease in employment rates and wage levels), which largely vary from one country to another. On the long-run, the negative effects of immigration tend to predominate. From the emigration perspective, the findings show some positive effects of labour emigration on sending countries, by enabling to upgrade the living standards for those remaining, mainly through remittances. Still, there is a negative impact generated on the size and structure of internal labour force and, on the long run, this is proving to be extremely negative (slow GDP per capita growth rates).
\end{abstract}

Keywords: Economic growth, European integration, Globalization, International migration, Labour market

\section{INTRODUCTION}

International migration as one of the most important frontiers of globalization represents a dynamic process that has significantly shaped the global economy. Nevertheless, both labour and humanitarian migration are key challenges especially for Europe, where the regional economic integration and the geopolitical context have generated increased immigration flows with profound economic consequences for migrant-sending and destination countries.

Within the European Union, OEDC (2014) shows that the migration flows registered a shift in trend during latest years, most migrants from Eastern Europe choosing Germany or Austria as main 
destination country compared to Italy and Spain that are still among the main host economies, but with a significant decrease compared to previous years (Noja et al., 2015, p. 98).
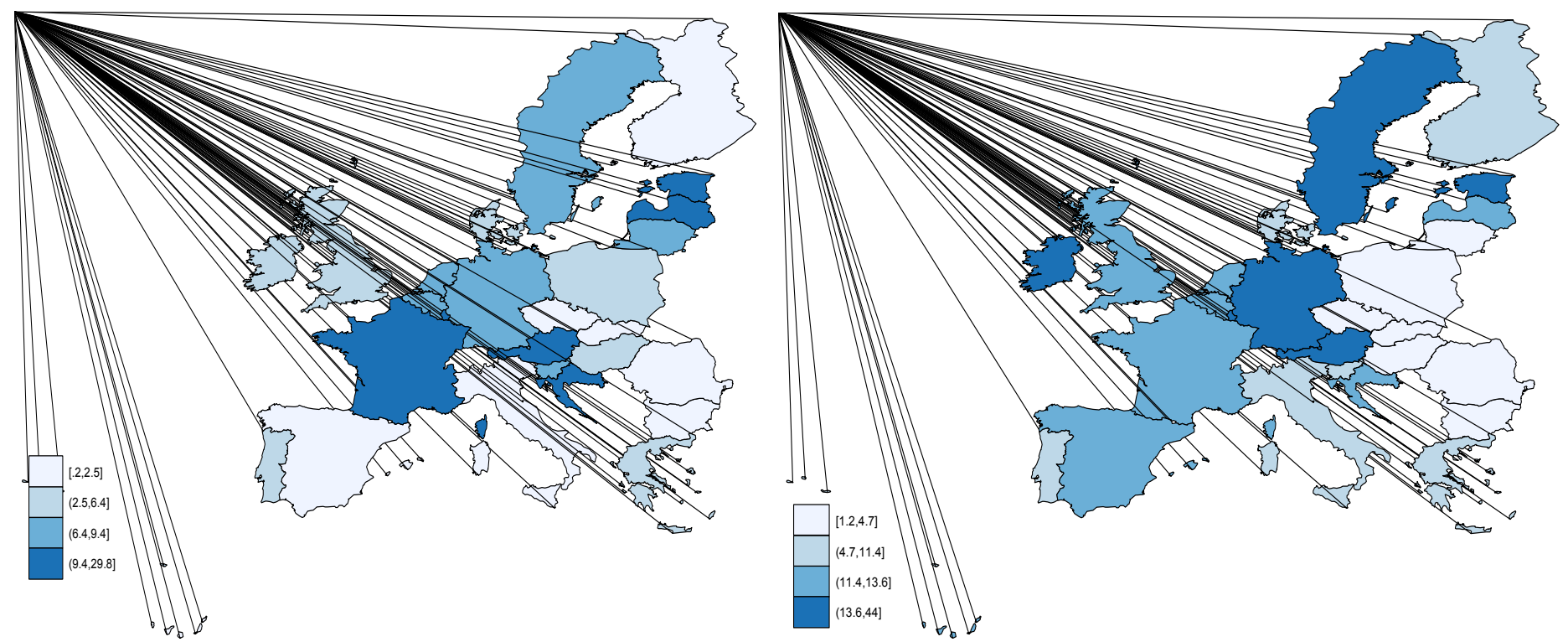

Figure 1: International migrant stock as a percentage of the total population (both genders), 1990 (left) and 2015 (right)

Source: own process based on UNHCR data through STATA 13

Moreover, the anxiety towards emigrants from Central and Eastern Europe in the context of the latest enlargements, mainly 2007 (Romania and Bulgaria) and 2013 (Croatia), but as well towards asylum seekers and refugees coming from Syria and other Arab countries highlights the importance of international migration policies, along with accurate and efficient immigrant integration strategies defined by the main European destination countries (Germany, Austria, Sweden).

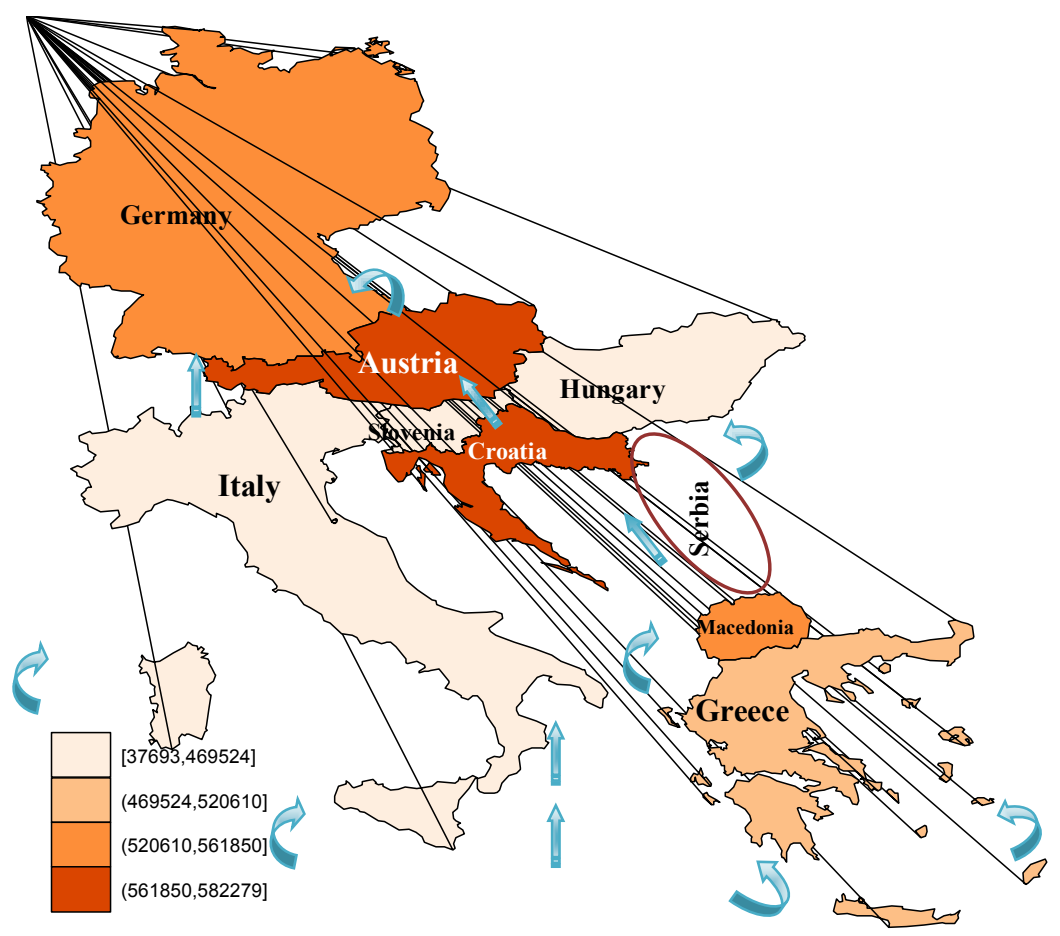

Figure 2: Refugee arrivals through Western Balkans and Central Mediterranean Route (Total October 2015 - February 2016)

Source: own process based on UNHCR data through STATA 13 
The Eastern Mediterranean and Western Balkans migration route is mainly used by asylum seekers coming from Syria, Iraq, and Afghanistan, being intensively over-passed by Pakistani and other groups of African migrants, as well as by other people that are leaving the Western Balkans territories for various reasons. Thus, in the first half of 2015, over 66000 people have crossed the Mediterranean between Turkey and Greece and more than 137000 people have been registered only in July and August.

The Central Mediterranean migration channel from Libya towards Italy is also intensively used, being registered for about 116000 sea arrivals by the end of August in 2015, compared to 172000 total people registered in 2014. Nevertheless, there is a swift in the nationalities of refugees. According to OECD (2015), until mid-2015, the main nationalities that have crossed this migration route were Eritreans (27\%), Nigerians (11\%), Somalians (9\%), Gambians (5\%) and Sudanese (5\%).

The third main migration channel towards Western Mediterranean was traditionally used by subSaharan migrants, but due to increased border controls and high cooperation with the Moroccan authorities, the route became less accessible.

As in the case of previous refugee crises in early 1990, the migration impact is cumulated in a few countries. Thus, across OECD, Turkey is the most affected hosting at present approximately 1.9 million Syrians, mostly with a temporarily protective status, as well as a significant number of people coming from Iraq. Moreover, other 300000 people, mainly from Afghanistan, Iraq and Pakistan have an illegal residence in Turkey waiting to transit towards the European Union to seek asylum. At the same time, more than 1.1 million Syrians find themselves in Lebanon, where the situation is increasingly uncertain, while a large number of refugees are in Jordan (about 630000) and Egypt (130000).

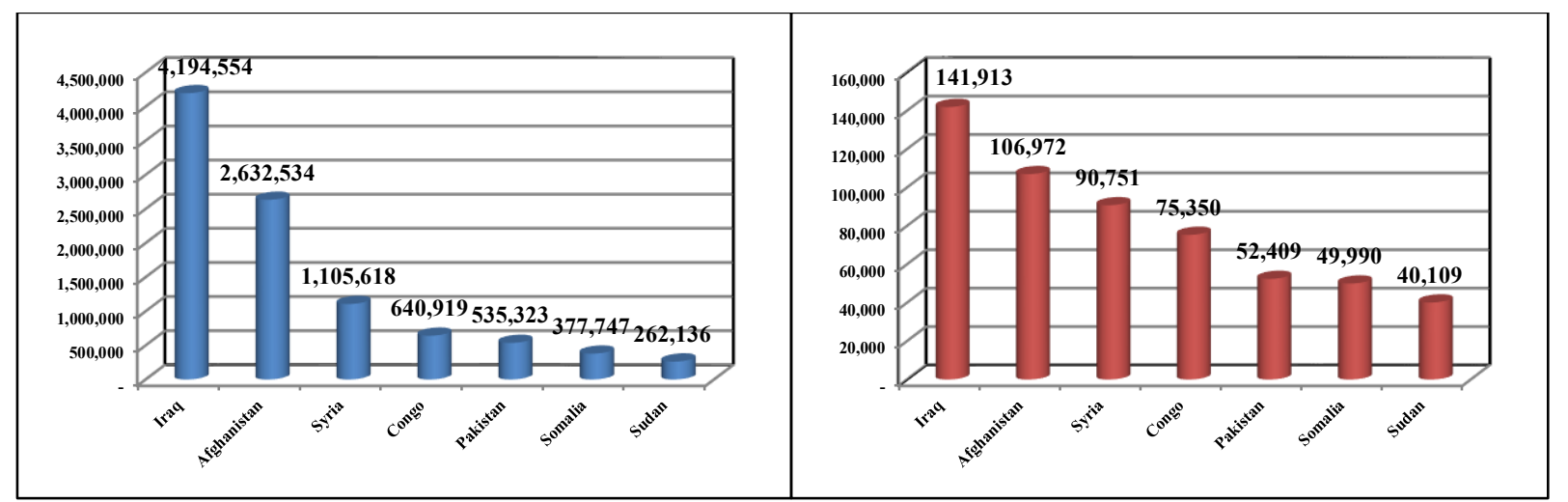

Figure 3: Refugees (left) and asylum seekers (right) by country of origin mid-2015 or latest available estimates

Source: own calculations based on UNHCR data

The large variety of migration corridors, migrant-sending countries and migration motives shape this refugee crisis into tough approach. Moreover, not only the fact that migrants came from various countries and territories of origin but at the same time, the main destination and asylum countries vary significantly across the EU. Thus, according to the OECD (2015), in Germany, during the first six months of 2015, Kosovo and Syria have each accounted $20 \%$ of the total asylum seekers, followed by Albania (15\%). In Sweden, Syrians have represented $27 \%$ of total migrants followed by Eritreans and Afghanis with few over $10 \%$, while Italy, Gambia was the first migrant sending country, followed by Senegal and Nigeria.

International migration as one of the most important frontiers of globalization represents a major challenge globally, with significant economic consequences, especially for Europe, where large migrant flows have emerged in the context of European integration. Moreover, recently there is an increased 


\section{Gratiela Georgiana Noja, Liana Son \\ Challenges of International Migration in a Globalized World: Implications for Europe}

waves of refugees and asylum seekers targeting Germany, Austria, Sweden or Turkey as main destination countries coming through Eastern and Central Mediterranean or Western Balkans routes.

Thus, immigration flows induce important effects within host economies leading to significant changes in labour market performances (slight decrease in employment rates and wage levels), both for native and foreign population, which largely vary from one country to another.

The paper aims to identify and assess the interdependencies between international migration and labour market outcomes, focusing both on emigration and immigration effects for sending and destination countries, as well as on economic (labour force) and non-economic (humanitarian, refugees) migration. The research offers a new insight to international migration and labour mobility within the European Union from a broad double perspective of emigration and immigration, economic and humanitarian sides, shaping factors and effects for migrant-sending and receiving economies.

\section{LITERATURE REVIEW}

The economic literature on various sides of the migration process is extremely large, starting with Ravenstein $(1885,1889)$ who has generalized the conclusions on internal migration in the United Kingdom in order to highlight that the intensity of the migration process is influenced by a complex set of factors, such as migrant personal characteristics (age, gender), the size of the population in sending and receiving countries, distance and the destination absorption capacity.

Later on, Hicks (1939) and Sjaastad (1962) made an assessment of international labour migration through an investment approach, considering it as a human capital development which implies an increase in migration flows, associated with lower costs and high incomes generated by the migration process. Their approach focuses on individual migration decisions and has shaped the main coordinates of the microeconomic neoclassic theory. Moreover, Todaro (1969) suggests that potential migrants select those destination countries which maximize the net present value of future expected incomes gained from migration, out of which they extract direct and indirect costs associated with the process (cost-benefit analysis). Thus, the migrants estimate the costs and benefits associated with moving into another country and decide to emigrate when net incomes are higher during a certain period of time (Borjas, 1989).

At the same time, Harris and Todaro (1970) have considered the impact generated upon the economic equilibrium by different policy instruments, like the minimum wage and restrictive migration legislation. Thus, Harris and Todaro (1970) developed a model which highlights that individuals are rationally responding to wage differentials between countries, and especially to income security, and to a smaller extent to real opportunities derived through migration, workers deciding to emigrate even is the possibility to earn a higher wage at the destination is limited.

As considering the both sides on international migration and the main research questions regarding the emigration impact on sending countries and immigration effects on native workers and host economies, there are various theories trying to solve these questions.

From the immigration perspective, Dustmann et al. (2008) have analyzed the labour market impact of immigration. The results of their study reveal that the way in which immigration influences the outcomes essentially depends on the skills structure of immigrants compared to the one held by native workers, education thus playing a decisive role. At the same time, the outcomes also depend on the assumptions on the elasticity of capital supply. Within this perspective, if the capital has a perfect elasticity, than the immigration won't influence the labour market performance for native workers since the immigrants share the same skills structure as them. Thus, the economy will incorporate the additional labour through its simple expansion. Still, on the other hand, if immigrants have different skills than natives and if there are no other adjustment mechanisms, then the absorption will imply various wage effects. Therefore, the benefits generated by immigration largely 
depend on the educational level of migrants and their skills structure compared to natives. Generally, immigration leads to a general redistribution in benefit of some and harm of others.

Krause et al. (2016) considered the labour market integration of migrants, focusing on the Single European Labour Market, its performances, risks, and opportunities, as well as the importance and usefulness of European labour mobility. Thus, they performed an online study among labour market exerts in Europe and concluded that most experts confirm the importance of a Single European Labour Market for improving the economic conditions, thus leading to welfare. Still, they seem to be uncertain about achieving these benefits. Moreover, in the case of EU labour mobility, the experts questioned by Krause et al. (2016) consider that the recognition of professional diplomas and qualifications, an optimization of the social security systems and over-passing the language barriers are some of the most important drivers to enhance labour mobility.

The emigration approach focuses more on migration effects on labour market outcomes, unemployment and economic growth generated by remittances and household impacts on those left behind. The large economic literature on the impact of labour emigration on migrant-sending economies highlights that it significantly depends on the way the capital-labour ratio is affected related to the people remaining in the origin country. Moreover, the emigration effects are extremely different from one socio-economic group to another. Thus, overall, emigration tends to have a positive impact on those remaining, by increasing the economic welfare and reducing income inequalities in migrant-sending countries (Clemens, 2011; de Haas, 2010; Taylor et al., 1996). At the same time, international labour migration ensures a temporary relaxation of the labour market pressures generated by high unemployment and, on the long run, the improvement of internal savings rate, as well as the profitable use of brain gain (return migration and migrant skills), lead to an increase in productive capital investments and new employment opportunities (job creation) (Goss and Lindquist, 1995). Nevertheless, Kwok and Leland (1982) synthesised the theories explaining the brain drain concept by revealing the relevance of asymmetric knowledge concerning the skills acquired by migrants, respectively the fact that the host country has more information on migrants' abilities than the migrant sending economy.

In Europe, Fertig and Kahanec (2015) have analysed the potential migration flows in the context of EU constant enlargement. Their results suggest that migration flows are largely shaped by policy variables and to a smaller extent by those economic and demographic. Thus, within the perspective of adopted and implemented migration policies, granting labour market free access to migrants by the hosting countries (Germany, Italy, and Austria, in absolute terms and relative to their population) significantly increases the migration waves, especially on the short run.

\section{METHODOLOGY}

\subsection{General form of developed models}

Our models follow the specific linear representation of the regression models with panel data, described by Baum (2001, p. 219) in order to proper analyse the emigration and immigration effects upon sending and receiving economies, configuration that was also used in previous researches (Son and Noja, 2012):

$$
\begin{aligned}
& y_{i t}=\sum_{k=1}^{k} x_{k i t} \beta_{k i t}+\varepsilon_{i t} \\
& i=1, \ldots, N \\
& t=1, \ldots, T
\end{aligned}
$$

where: $\mathrm{N}$ is the number of panel units (countries), while T represents the number of periods (time). The fixed effects model or the Least Squares Dummy Variable (LSDV) model has the following representation (Baum, 2001, p. 220):

$y_{i t}=x_{i t} \beta_{k}+z_{i} \delta+u_{i}+\varepsilon_{i t}$ 


\section{Gratiela Georgiana Noja, Liana Son \\ Challenges of International Migration in a Globalized World: Implications for Europe}

where $x_{i t}$ is a $1 \times k$ vector of variables varying between countries and in time, $\beta$ represents a $1 \times k$ vector of $x$ coefficients, $z_{i}$ is a $1 \times p$ vector of the variables that are constant in time, but vary between countries (as elements of the panel), $\delta$ represents a $p \times 1$ vector of $z$ coefficients, $u_{i}$ is the individual effects, for every element of the panel, and $\varepsilon_{i t}$ is the disturbance term.

The random effects model or the Error Component Model (ECM) has the following representation (Baum, 2001, p. 227):

$y_{i t}=x_{i t} \beta+z_{i} \delta+\left(u_{i}+\varepsilon_{i t}\right)$

where: $u_{i}+\varepsilon_{i t}$ represents the compouned disturbance term, and $u_{i}$ reflects the individual effects.

The models developed in order to assess the immigration effects upon native workers and host country's labour market, including humanitarian migration, as well to evaluate the emigration impacts on sending economies, follow the specification of double-log simple and multiple regression models with panel data. These models were processed through OLS and GLS methods of estimation in the case of fixed and random effects, respectively through the panel corrected standard errors method (PCSE) and maximum likelihood (MLE) in the case of SEM modelling of emigration effects.

\subsection{Variables and indicators used for the empirical analysis}

In the analysis we focused on the international migration effects on economic growth and labour market fundamentals (unemployment, employment, wages, earnings), respectively on the educational background (upper secondary and/or tertiary) within the context of the globalization process and increased interdependencies between the economies globally. We, thus, selected a large scale of indicators as proxy for the variables of developed models, ranging from the economic activity, labour market outcomes and education to various sides of the international migration process (immigration vs. emigration, labour vs. humanitarian migration), thus comprising:

i) international migration specific indicators: immigration flows and stocks, flows of refugees and asylum seekers, the stock of emigrants, remittances (mil. USD);

ii) economic activity and labour market indicators: total (mil. Euro) and per capita (Euro) GDP and the GDP per person employed (USD); employment and unemployment rates (\%); earnings by two-earner married couple with two children (Euro) and earnings dispersion among employees (Decile 9/ Decile 5 ), average annual wages (USD); the educational attainment (both general and vocational) through secondary and tertiary education levels (the highest ISCED - International Standard Classification of Education level successfully completed) and the participation rate in education covering participation in formal and non-formal education and training;

iii) the globalization process: KOF Index of Economic Globalization and the value added by foreigncontrolled enterprises as a share of total value added (foreign affiliate statistics).

The panel structure covers five main EU destination countries (Germany, Austria, Sweden, Italy and Spain) and three New EU Member States since 2007 (Romania and Bulgaria) and 2013 (Croatia). Within the performed analysis we covered the 2000-2014 period of time and used as main data sources the statistical database of the European Commission - Eurostat, the international migration database of OECD, World Bank - World Development Indicators and United Nations Database UNHCR, ETH Swiss Federal Institute of Technology Zurich, UNU WIDER World Income Inequality Database.

\section{ANALYSIS OF THE RESULTS}

The empirical analysis conducted within this paper has a double objective: (i) first, to identify and analyse the immigration effects on native workers and receiving countries, including labour immigration flows/ stocks and asylum seekers and (ii) second, to evaluate the emigration impacts on migrant sending economies. The main research limit for the performed empirical analysis is the lack of proper data detailed on long time series for international migration (especially official data on emigration). Thus, in order to complete the database and provide accurate results for our developed 


\section{Gratiela Georgiana Noja, Liana Son}

Challenges of International Migration in a Globalized World: Implications for Europe

models, we proceeded to interpolation and extrapolation in the early phase of the research for some of the indicators used as variables in designed models.

Our first set of double log simple regression models focus on the immigration impact on GDP per capita for the five main EU destination countries.

Table 1: Results of the models developed for the analysis of immigration economic consequences

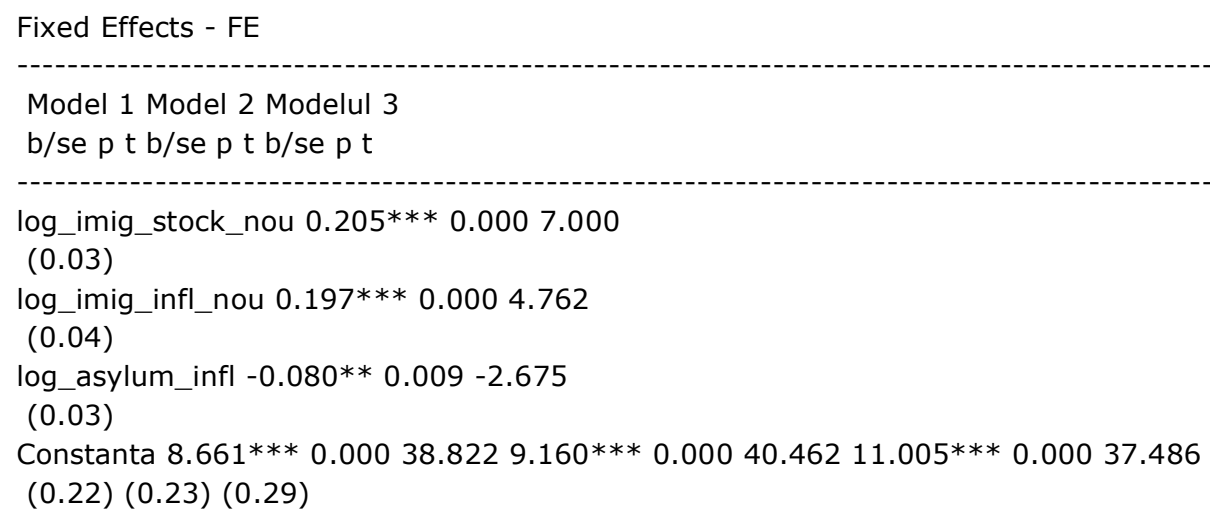

Moreover, we expanded our immigration analysis using the same three dimensions and associated indicators (stock of immigrants, immigration flows and asylum seekers) by developing another set of seven models that capture the immigration effects on GDP per person employed (model 1), wage levels (model 2), overall earnings of a couple with two children (model 3), earnings dispersion (model 4 ), employment rate (model 5), secondary education background (model 6) and participation rate in education (model 7 ). 
Table 2: Results of the seven models developed for the extended analysis of immigration economic consequences

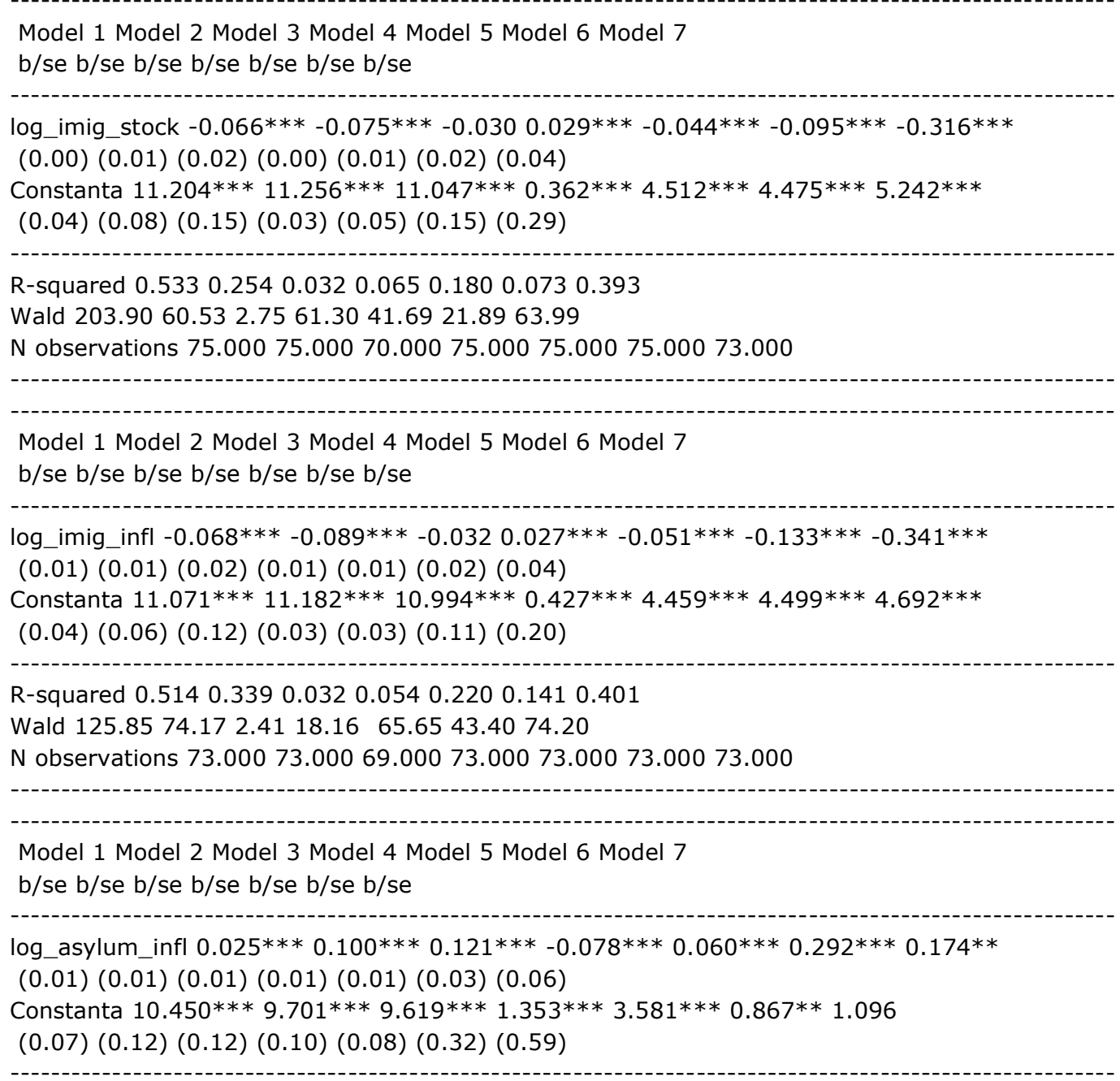

R-squared 0.0620 .3710 .4300 .3890 .2810 .5650 .095

Wald 12.9667 .4189 .6261 .1357 .5179 .299 .25

N observations 75.00075 .00070 .00075 .00075 .00075 .00073 .000

$* \mathrm{p}<0.05, * * \mathrm{p}<0.01, * * * \mathrm{p}<0.001$

Source: own process of panel data through STATA 13 econometric package

The results show that there is evidence to confirm the concerns regarding a generally negative impact of immigration on the five destination economies analysed within the panel and their native workers. Thus, even though in the first set of models processed through fixed and random effects only the increase in asylum seekers inflows lead to a decrease in GDP per capita, while the immigration stocks and inflows generate a slight increase in the overall economic welfare, the second set of seven models processed through PCSE confirms the negative impact of immigration, especially in terms of labour market outcomes.

Within this context, an increase in both immigration stocks and flows induces a decrease in GDP per person employed, wage levels and of the overall earnings obtained by a couple with two children, with an associated increase in earnings dispersion. Moreover, the adverse impact is shown in the case of employment levels, with a slight decrease in the employment rate, as well as in the educational background by reducing the educational attainment of upper secondary level and the participation rate in education. Moreover, the models show a tight interdependence between the variations in 
immigration flows/ stocks and the degree of participation in education, GDP per person employed and wage levels, as shown by the r-squared.

From the emigration perspective, we analysed the impact generated by the stock of emigrants (job seekers) upon the sending country's GDP per capita, both through losing a large part of its labour force and by remittances, in the present context of a globalised world economy. Thus, we developed a SEM model for the three sending economies, EU New Member States since 2007 and 2013, focusing on the shaping factors of emigration stocks and their aggregate impact on the economy.
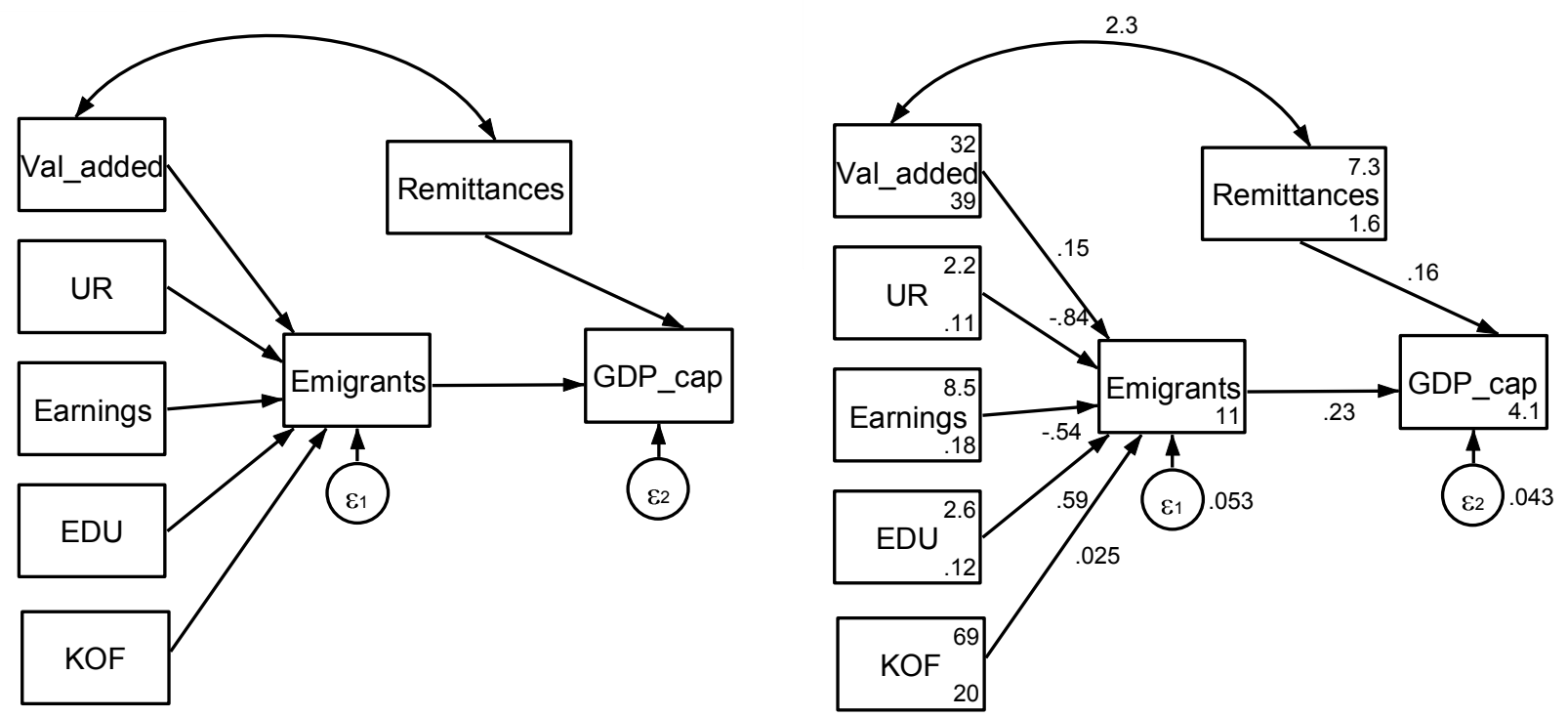

Figure 4: General form of the SEM model developed for the emigration analysis

Source: own process of panel data through STATA 13 econometric package

The results highlight that an improvement in the educational level generates an increase in the emigrant stocks thus confirming the selection of migrants at destination according to their educational background and the brain drain theories. Moreover, an increase in the overall earnings of a household tends to discourage emigration, as well as the labour market performances like increases in employment rates.

Table 3: Results of the SEM models developed for the assessment of emigration impacts on sending economies

Model 1 Model 2 Model 3

$\mathrm{b} / \mathrm{se} \mathrm{pt} b / \mathrm{se} \mathrm{pt}$ b/se $\mathrm{pt}$

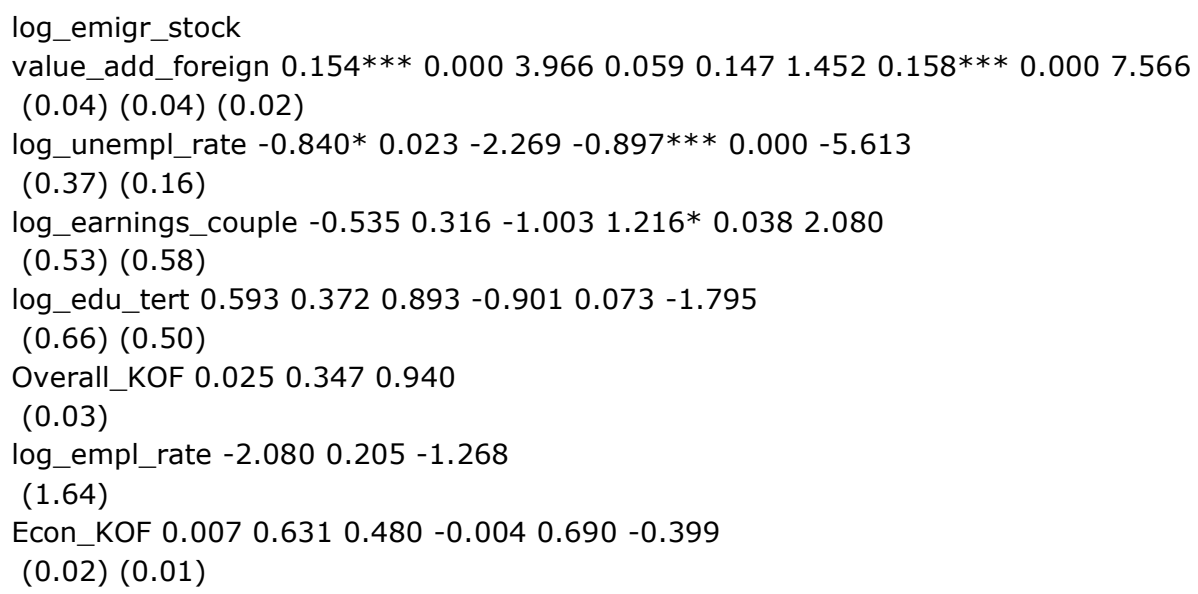




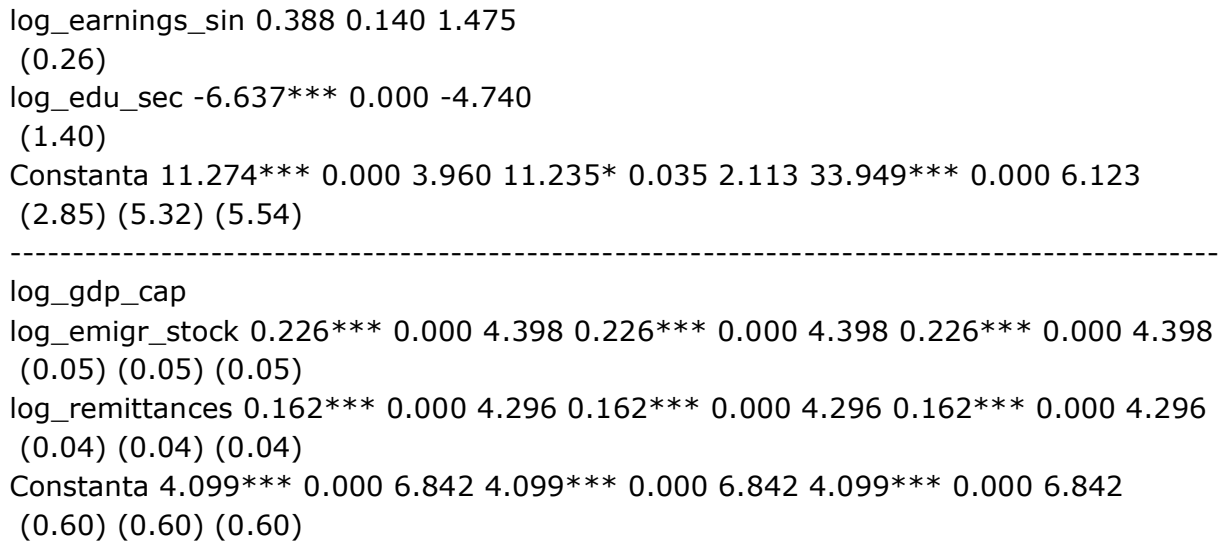

Source: own process of panel data through STATA 13 econometric package

Nevertheless, an increase in interdependencies between countries and the free movement reassuring within the context of economic globalization tends to encourage international migration, by increasing the stock of emigrants for the three considered sending economies (by $0.025 \%$ according to our results). The overall impact of emigration on the three considered countries tends to be a positive one, attested by an increase in GDP per capita both through remittances and emigration stocks (some possible explanations could refer to various incentives for those remaining, including additional investments, productivity increases or the relaxation of high unemployment pressures).

\section{CONCLUDING REMARKS}

International migration is an extremely complex process with significant effects both for migrantsending and receiving economies, labour markets and for individuals and their families (labour and humanitarian migration). Our results show that international migration generates significant effects and different labor market outcomes, very controversial for some of the analyzed countries, both positive and negative.

The main negative impact generated by immigration within the main destination countries, especially when we consider the labour migration and less in the case of asylum seekers happens mainly because of the temporary and transitional character of the humanitarian flows. Thus, migrant host economies need to consider several specific labour market policies in order to cope with large inflows of immigrants and refugees. Active labour market policies (ALMPs) centre on unemployed people, their implementation providing assistance in finding a job, training for professional development and skills acquirement, wage incentives and direct job creation in the public sector. All of these are extremely necessary for the inclusion of immigrants. The flexicurity policies combine the two perspectives on flexibility and security as main components of European employment strategies. Thus, the overall focus should be on new employment guidelines and job creation for a better coordination of the compatibility between labour demand and supply, together with an improvement in the educational level of the labour force, better working conditions and wage increases.

The main emigration effects derived from the performed analysis are generally positive in terms of economic growth through remittances, thus leading to an improvement in living standards for those remaining. Moreover, the educational level of migrants and the globalization process mainly reflected here by increased interdependencies between national economies through the international flows of goods, services and capital (respectively international trade and investments as a share of the GDP) represent the main shaping factors of the emigration stocks, by inducing their increase.

In terms of labour market outcomes, the emigration process tends to temporary ease the pressures generated by high unemployment rates, thus leading to a slight employment increase. Still, there is a 
negative impact generated on the size and structure of internal labour force and, on the long run, this is proving to be extremely negative (slow GDP per capita growth rates).

\section{REFERENCES}

- Borjas J. George (1989), "Economic Theory and International Migration”, International Migration Review, Special Silver Anniversary Issue: International Migration an Assessment for the 90's, The Centre for Migration Study of New York, vol. 23, no.3, pp. 457-485.

- Baum F. Christopher (2001), "An Introduction to Modern Econometrics Using STATA”, STATA Press, ISBN 1-59718-013-0, pp. 1-341.

- Clemens Michael (2011), "Economics and Emigration: Trillion-Dollar Bills on the Sidewalk?", Journal of Economic Perspectives, Vol. 25, No. 3, pp. 83-106.

- Dustmann Christian, Frattini Tommaso, Glitz Albrecht (2008), "The Labour Market Impact of Immigration", CReAM Discussion Paper no. 11, Centre for Research and Analysis of Migration, Department of Economics, University College London, pp. 1-27.

- Fertig Michael, Kahanec Martin (2015), "Projections of potential flows to the enlarging EU from Ukraine, Croatia and other Eastern neighbours", IZA Journal of Migration, no. 4, issue 6, pp. 127.

- Goss Jon, Lindquist Bruce (1995), "Conceptualizing International Labor Migration: A Structuration Perspective", International Migration Review, Vol. 29, No. 2, pp. 317-351.

- Harris R. John, Todaro P. Michael (1970), "Migration, Unemployment and Development: a TwoSector Analysis", The American Economic Review, volume 60, issue 1, pp. 126-142.

- Hein de Haas (2010), "Migration and Development: A Theoretical Perspective", International Migration Review, Vol. 44, No. 1, pp. 227-264.

- Hicks John Richard (1939), "The foundation of welfare economics", The Economic Journal, issue 49, pp. 696-712.

- Krause Annabelle, Rinne Ulf, Zimmermann Klaus (2016), „European Labour Market Integration: What the Experts Think", forthcoming International Journal of Manpower 2016, IZA Discussion Paper no. 8383, pp. 1-27.

- Kwok Viem, Leland Hayne (1982), "An Economic Model of Brain Drain”, American Economic Review, Vol. 72, No. 1 (March 1982), pp. 91-100.

- Noja Gratiela Georgiana, Son Liana, Caran Margareta (2015), "Key Challenges of Emigration from Central and Eastern European Economies: Empirical Evidence", The Macrotheme Review, no. 4, issue 6, pp. 97-110.

- OECD (2015), "Is this humanitarian migration crisis different?", Migration Policy Debates, no. 7, September 2015.

- OECD (2014), International Migration Outlook, Mobilising Migrants' Skills for Economic Success.

- Ravenstein Ernst Georg (1889), "The Laws of Migration: Second Paper", Journal of the Royal Statistical Society, Volume 52, No. 2, pp. 241-305.

- Ravenstein Ernst Georg (1885), "The Laws of Migration", Journal of Statistical Society, Volume 48, No. 2, pp. 167-235.

- Sjastaad A. Larry (1962), "The Costs and Returns of Human Migration", The Journal of Political Economy, Vol. 70, No. 5, Part 2: Investment in Human Beings (October 1962), pp. 80-93.

- Son Liana, Noja Gratiela (2012), "A macroeconometric panel data analysis of the shaping factors of labour emigration within the European Union", Theoretical and Applied Economics, Vol. XIX, No. 11(576), pp. 15-30.

- Todaro P. Michael (1969), „A model of labour migration and urban unemployment in less developed countries", American Economic Review, issue 69, pp. 486-499.

- Zimmermann F. Klaus (2005), European Migration: What Do We Know?, Oxford University Press, New York, ISBN 978-0-19-925735-5, pp. 1-653. 